\title{
Vascular reactivity in diabetes mellitus: possible role of insulin on the endothelial cell
}

\author{
Zuleica B. Fortes, J. Garcia Leme \& Regina Scivoletto \\ Department of Pharmacology, Institute of Biomedical Sciences, University of São Paulo, 05508 São Paulo, \\ Brazil
}

1 The response to vasoactive agents of microvessels of the rat was tested in vivo by direct microscopic observation of the exteriorized mesentery and assessment of cutaneous vascular permeability changes with Evans blue.

2 The constrictor response to a standard amount of noradrenaline in mesenteric microvessels was fully antagonized by acetylcholine in normal, diabetic, adrenalectomized and diabeticadrenalectomized rats. In contrast, the minimum doses of histamine or bradykinin, effective in normal or adrenalectomized animals, had to be increased about 20 fold to be active in diabetic or diabetic-adrenalectomized animals.

3 Topical application of insulin to mesenteric microvessels of diabetic animals, in amounts not causing any increase in serum insulin levels, improved or restored the capacity of the animals to respond to histamine or bradykinin, acting as antagonists of the vasoconstrictor response to noradrenaline. Topical insulin, however, was ineffective in normal animals given 2-deoxyglucose, the acute effects of which result from cellular glucopaenia unrelated to insulin deficiency.

4 Vascular permeability responses to intracutaneous histamine or bradykinin were decreased in animals pretreated with 2-deoxyglucose as much as in diabetic animals.

5 Pretreatment of normal animals with indomethacin produced no effect on the responses of these animals to histamine or bradykinin, tested as antagonists of noradrenaline on mesenteric microvessels, or as vascular permeability-increasing factors in the skin.

6 Pretreatment of normal animals with chloroquine, mepacrine or dexamethasone had no effect on the reactivity of mesenteric microvessels to histamine and bradykinin, acting as antagonists to noradrenaline.

7 It is suggested that vasoactive substances, endowed with permeability-increasing properties, evoke relaxation of microvessels through an insulin-dependent action on endothelial cells, unrelated to the release of arachidonic acid metabolites. This action would lead to increased vascular permeability, with opening of interendothelial junctions, and temporary changes in composition of extravascular fluid, which in turn, would provide the basis for vasodilatation. Diabetes mellitus apparently impairs such responses as a result of the accompanying cellular glucopaenia. Adrenal corticosteroids are not involved in the impaired responses.

\section{Introduction}

Abnormalities of microvascular responsiveness to chemical, physical and neurohumoral agents occur in diabetes mellitus (Garcia Leme et al., 1973; 1974 Altura et al., 1979). The functional changes observed cannot always be ascribed to a defective response of the vascular smooth muscle and in many instances, they are acutely reversed by systemic administration of insulin (Fortes et al., 1983a,b). There is evidence to show that endothelial cells play an obligatory role in vascular responses to drugs (Furchgott \& Zawadzki, 1980; Chand \& Altura, 1981a; Van de Voorde \& Leusen, 1982). An acute effect of insulin on endothelial cells of the microcirculation, has been described (Osterby et al., 1978).

The present experiments were undertaken to investigate the participation of endothelial cells in the impaired responses of diabetic animals to vasoactive agents. 


\section{Methods}

Male Wistar rats, $100-150 \mathrm{~g}$ body weight, were used for studies on mesenteric microvessels in situ, or for the assessment of vascular permeability responses to substances injected intracutaneously.

\section{Procedures with mesenteric microvessels}

The mesentery was exteriorized and arranged for microscopic observation in situ according to a slight modification of the method of Zweifach (1948). The animals, under chloral hydrate anaesthesia (400-450 $\mathrm{mg} \mathrm{kg}^{-1}$, s.c.), were kept on a special board, heated to $37^{\circ} \mathrm{C}$, which included a transparent plate on which the tissue to be trans-illuminated was placed. The mesentery was kept moist and warmed by irrigating the tissue with warmed $\left(37^{\circ} \mathrm{C}\right)$ Ringer-

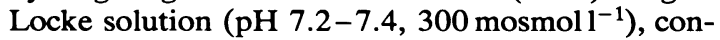
taining $1 \%$ gelatin. The composition of the solution was (mM): $\mathrm{NaCl} 154, \mathrm{KCl} 5.6, \mathrm{CaCl}_{2} 2, \mathrm{NaHCO}_{3} 6$ and glucose 5 , and its osmolarity checked by the freezing-point depression method (Fiske osmometer). The rate of outflow of the solution onto the exposed tissue was controlled to maintain the mesentery in continuous contact with a film of the liquid. After selecting a suitable microscopic field, observed at a magnification of $100 \times$, the preparation was standardized on the basis of the response to $0.01 \mathrm{ml}$ of a $3 \mu \mathrm{g} \mathrm{ml}^{-1}$ solution of noradrenaline applied topically. The response was characterized by the complete cessation of blood flow withing 12 to $25 \mathrm{~s}$ in one or more vessels of the microscopic field. The observation was restricted to non-capillary vessels, capillaries being excluded on the basis of their diameter. Experiments were designed to evaluate the antagonistic effect on this response of histamine or bradykinin, applied topically in a standard volume of $0.01 \mathrm{ml}$. Noradrenaline was added 15 to $30 \mathrm{~s}$ after the application of the agent to be tested as antagonist. A complete series of tests comprised the following steps, with a 3 min interval between each step: (a) application of noradrenaline and determination of latency time to observe a response; (b) addition of the agent to be tested as antagonist, followed by application of noradrenaline; any drug effects were followed up to $90 \mathrm{~s}$; (c) addition of the standard dose of noradrenaline to test recovery. Drugs were removed between each step by washing out with the warmed Ringer-Locke solution. A given section of the vascular bed was tested only once and no more than 3 series were performed on a single animal. All drugs added to the preparation were dissolved in Ringer-Locke solution. The animals in this group of experiments were allocated as follows: (i) alloxandiabetic rats; (ii) diabetic adrenalectomized rats; (iii) adrenalectomized rats; (iv) normal rats receiving 2- deoxyglucose, indomethacin, mepacrine, chloroquine or dexamethasone, intravenously; (v) matching controls for each of the preceding groups. In a group of alloxan-diabetic rats and matching controls insulin was applied topically to the preparation and its effects on the responses of microvessels to noradrenaline and the antagonistic agents tested. In these animals serum insulin levels were determined at the end of the experiments.

\section{Assessment of vascular permeability responses with Evans blue}

Measurement of permeability effects was performed according to Wilhelm et al. (1958). The fur on the dorsal trunk was shaved and, immediately before testing, the animals were given intravenous Evans blue, $25 \mathrm{mg} \mathrm{kg}^{-1}$ as a $2.5 \%$ solution in $0.45 \% \mathrm{NaCl}$. The substances to be tested were made up in RingerLocke solution and injected intracutaneously, in a standard volume of $0.1 \mathrm{ml}$. Each animal received 8 intracutaneous injections in the skin of the dorsal trunk. The 8 intracutaneous injections comprised different doses of histamine or bradykinin, plus 1 control injection of $0.1 \mathrm{ml}$ Ringer-Locke solution. The sites of injection of each dose were varied from animal to animal, the rats being kept under light ether anaesthesia during injection of the substances. Twenty min after injections, the animals were killed and the whole thickness of the skin reflected from the dorsal trunk. The content of exuded dye in the lesions was estimated by excising the skin and holding the minced skin from each lesion in $4 \mathrm{ml}$ formamide at $37^{\circ} \mathrm{C}$ for $24-30 \mathrm{~h}$. The resultant solution was filtered and the optical density of the filtrate assessed colorimetrically at $619 \mathrm{~nm}$. The concentration of dye in the filtrate was estimated from a standard graph recording the optical density of serial dilutions of a weighed sample of Evans blue in formamide. Permeability effects were estimated in: (i) alloxan diabetic rats; (ii) normal rats receiving 2-deoxyglucose, indomethacin or chloroquine, intravenously; (iii) matching controls for each of the preceding groups. Results are expressed after correction by subtraction of values for the corresponding injection of RingerLocke solution.

\section{Determination of blood pressure}

In animals given indomethacin, mepacrine, chloroquine or dexamethasone, systolic blood pressure was determined with a plethysmograph immediately before the experiments. The method used unanaesthetized rats and was slight modification of that described by Williams et al., (1939). 


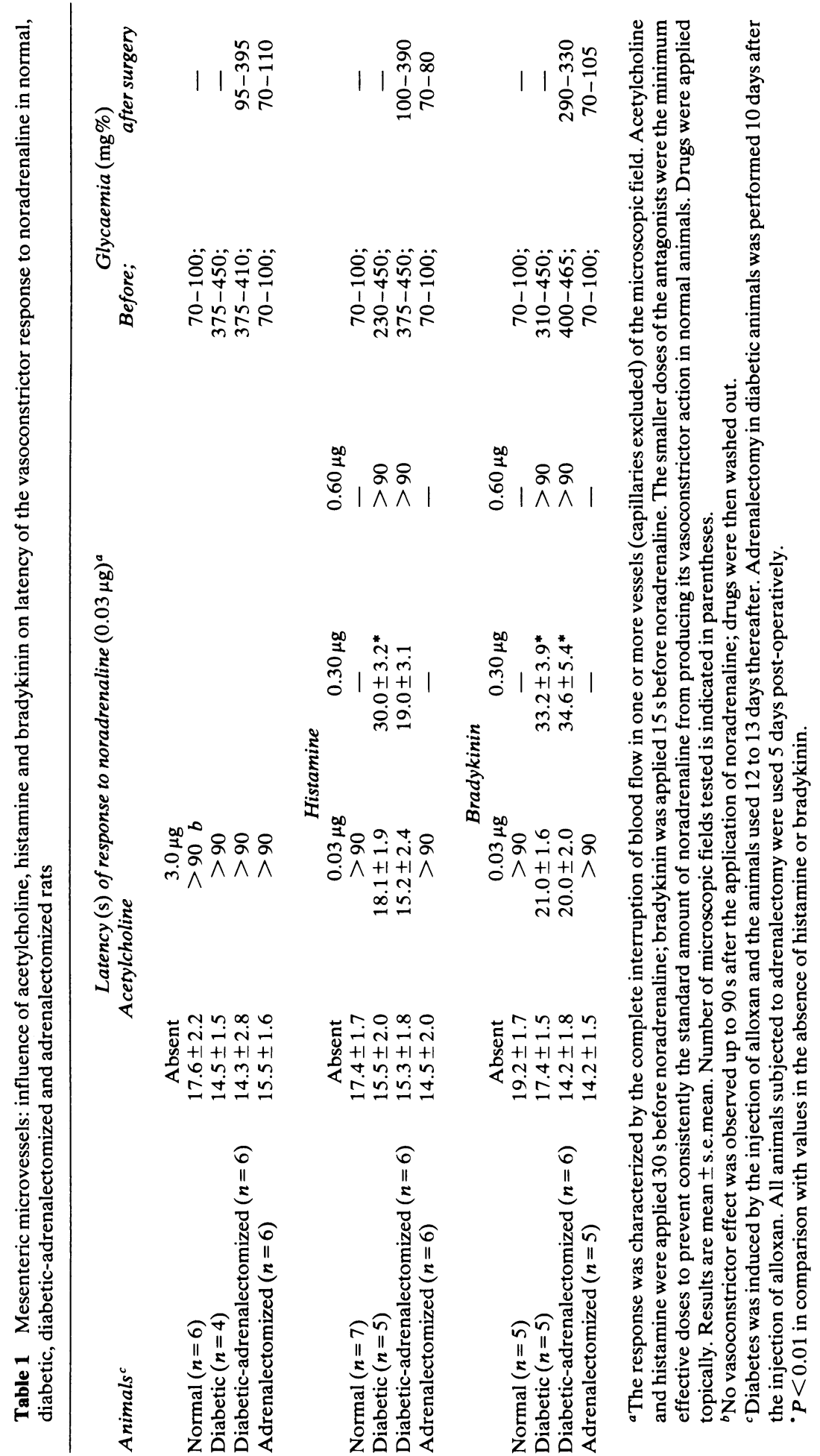




\section{Production of alloxan-diabetic rats}

The animals were fasted for $15 \mathrm{~h}$, with water ad libitum, then injected intravenously with alloxan $40 \mathrm{mg} \mathrm{kg}^{-1}$. The effect of the drug was assessed 10 days later, by determination of blood sugar levels as described by King \& Garner (1947). Animals with glycaemia above $200 \mathrm{mg} 100 \mathrm{ml}^{-1}$ were used in the subsequent 2-3 days. Matching controls were kept in similar conditions during the same time interval, and their blood sugar levels then estimated.

\section{Surgical procedures}

Surgery was performed under ether anaesthesia. The two adrenal glands were removed through a small midline incision in the skin of the dorsal trunk with entrance into the peritoneal cavity through bilateral muscle incisions (Waynforth, 1980). Adrenalectomized animals were supplied with physiological saline in addition to water. Diabetic animals were adrenalectomized 10 days after alloxan injection. The animals were used 5 days post-operatively.

\section{Radioimmunoassay for insulin}

Insulin was measured in $0.1 \mathrm{ml}$ serum according to Morgan \& Lazarow (1963) using $\left[{ }^{125} \mathrm{I}\right]$-insulin as a tracer.

\section{Drugs}

The following were used: alloxan hydrate (Carlo Erba); bradykinin triacetate (Sigma); chloroquine (Winthrop); 2-deoxy-D-glucose (Sigma); dexamethasone sodium phosphate (Merck, Sharp \& Dohme); histamine hydrochloride (Carlo Erba); indomethacin (Merck, Sharp \& Dohme); crystalline bovine insulin (Sigma); mepacrine (Rhodia) and (-)-noradrenaline bitartarate (Sigma).

\section{Statistical analysis}

Mean values were compared by analysis of variance. To test differences among means the $\mathrm{Q}$ method was used (Snedecor \& Cochran, 1974). Intercepts and slopes of log dose-response lines were calculated by

Table 2 Mesenteric microvessels: influence of topical application of 1 mu crystalline insulin on latency changes of the vasoconstrictor response to noradrenaline induced by histamine and bradykinin in normal and diabetic animals

Animals

$\mathbf{A}$

Diabetic $^{c}$

Normal

B

Diabetic

Normal

\section{Latency (s) of the response to noradrenaline} $(0.03 \mu \mathrm{g})^{a}$ following the application of

\section{Glycaemia \\ (mg\%)}

Insulin + histamine

Insulin

$(0.03 \mu \mathrm{g})$

Insulin + bradykinin

$$
\begin{gathered}
17.4 \pm 4.3 \\
(n=7) \\
>90^{b} \\
(n=6)
\end{gathered}
$$

$(0.03 \mu \mathrm{g})$

$$
\begin{array}{cc}
15.5 \pm 1.5 & 16.4 \pm 2.0 \\
(n=15) & (n=13) \\
14.6 \pm 1.3 & 17.8 \pm 2.6 \\
(n=16) & (n=6)
\end{array}
$$

$$
\begin{gathered}
14.7 \pm 1.9 \\
(n=7) \\
17.1 \pm 1.1 \\
(n=9)
\end{gathered}
$$
$29.6 \pm 2.7^{*}$$$
(n=7)
$$$$
>90
$$$$
(n=5)
$$

$270-440$

$70-100$

$>90$

$(n=9)$

$$
\begin{gathered}
>90 \\
(n=8) \\
>90 \\
(n=5)
\end{gathered}
$$

$280-430$

$70-100$

Time of contact of insulin with the preparation before the addition of any other drug: A, $1 \mathrm{~min} ; \mathrm{B}, 3 \mathrm{~min}$. ${ }^{a}$ The response was characterized by the complete interruption of blood flow in one or more vessels (capillaries excluded) of the microscopic field. Histamine and bradykinin were applied $30 \mathrm{~s}$ and $15 \mathrm{~s}$ before noradrenaline, respectively. The doses of histamine and bradykinin were the minimum effective doses to prevent consistently the standard amount of noradrenaline from producing its vasoconstrictor action in normal animals. Drugs were applied topically. Insulin alone produced no response of the preparation in both groups of animals. Results are mean \pm s.e.mean. Number of microscopic fields tested is indicated in parentheses.

${ }^{b}$ No vasoconstrictor effect was observed up to $90 \mathrm{~s}$ after the application of noradrenaline: drugs were then washed out.

${ }^{c}$ Diabetes was induced by the injection of alloxan and the animals used 12 to 13 days thereafter.

$\cdot P<0.01$ in comparison with values in the absence of histamine and bradykinin. 
linear regression and compared by analysis of variance. $P<0.01$ was taken as being statistically significant.

\section{Results}

\section{Mesenteric microvessels}

Responses to vasoactive agents and the effect of insulin Noradrenaline (NA) at a dose of $0.03 \mu \mathrm{g}$ applied topically to mesenteric microvessels induced in normal, diabetic, diabetic-adrenalectomized and adrenalectomized animals a response characterized by the complete interruption of blood flow in one or more (non-capillary) vessels of the microscopic field. This response was evoked within 12 to $25 \mathrm{~s}$ of drug addition. Acetylcholine ( $\mathrm{ACh}$ ) applied topically to the preparations $30 \mathrm{~s}$ beforehand, at the minimum effective dose of $3 \mu \mathrm{g}$, antagonized the vasoconstrictor response to NA in all groups of animals. In these circumstances, no vasoconstrictor response was observed up to $90 \mathrm{~s}$ after the application of NA. In contrast, the minimum effective doses of histamine $(0.03 \mu \mathrm{g})$ and bradykinin $(0.03 \mu \mathrm{g})$ capable of antagonizing consistently the response to NA in normal and adrenalectomized animals had to be increased about 20 fold to block the response of diabetic or diabetic-adrenalectomized rats to the vasoconstrictor agent in the subsequent $90 \mathrm{~s}$ interval. Results are summarized in Table 1 . Topical application to the preparation of $1 \mathrm{mu}$ crystalline insulin did not evoke any response of the microvessels and yet improved or completely restored the capacity of diabetic animals to respond to histamine or bradykinin, tested as antagonists of the vasoconstrictor response to NA. Insulin was left in contact with the preparation during 1 or $3 \mathrm{~min}$ prior to the addition of histamine or bradykinin(Table 2 ). The amount of insulin added did not cause any significant change in serum insulin levels of either normal or diabetic rats (Table 3 ). On the other hand, topical insulin was ineffective in correcting the decreased sensitivity to histamine or bradykinin in animals in which cellular glucopaenia, secondary to inhibition of glucose utilization, was induced by previous administration of 2deoxyglucose (2DG) (Table 4).

\section{Effect of inhibition of arachidonic acid metabolism}

Pretreatment of normal animals, by the intravenous route, with indomethacin (up to $5 \mathrm{mg} \mathrm{kg}^{-1}$ ), mepacrine (up to $10 \mathrm{mg} \mathrm{kg}^{-1}$ ), and chloroquine (up to $\left.25 \mathrm{mg} \mathrm{kg}^{-1}\right) 30 \mathrm{~min}$ before testing, or with dexamethasone (up to $10 \mathrm{mg} \mathrm{kg}^{-1}$ ) 1 to $2 \mathrm{~h}$ before testing, did not affect the responses of the animals to NA. In addition $\mathrm{ACh}$, histamine or bradykinin remained fully active in antagonizing the vasoconstrictor re-
Table 3 Serum insulin levels, estimated by radioimmunoassay, and glycaemia in normal and diabetic rats following topical application to mesenteric microvessels of 1 mu crystalline insulin

$\begin{array}{lccc}\text { Animals } & \begin{array}{c}\text { Topical } \\ \text { insulin }^{a}\end{array} & \begin{array}{c}\text { Serum insulin } \\ \text { levels }\left(\mu \mathrm{u} \mathrm{ml} \mathrm{m}^{-1}\right)\end{array} & \begin{array}{c}\text { Glycaemia } \\ (\mathrm{mg} \%)\end{array} \\ \text { Normal } & \text { Yes } & 50-60 & 60-90 \\ & \text { No } & 42-57 & 60-90 \\ \text { Diabetic }^{b} & \text { Yes } & 8-30 & 300-450 \\ & \text { No } & 11-32 & 290-430\end{array}$

${ }^{n}$ Crystalline insulin, in a standard volume of $0.01 \mathrm{ml}$ was left in contact with the preparation for $5 \mathrm{~min}$ and blood collected immediately thereafter. All animals were fasted for $5 \mathrm{~h}$ before the exteriorization of the mesentery, which was performed as for previous experiments. Four animals were used in each group.

${ }^{b}$ Diabetes was induced by the injection of alloxan and the animals used 12 to 13 days thereafter.

sponse to NA in these animals (data not shown). Blood pressure levels determined in unanaesthetized animals following pretreatment with the various drugs did not deviate significantly from normal values. This was assumed to indicate that, in the range of doses employed, the drugs did not evoke acute toxic effects.

\section{Vascular permeability responses}

Assessment of vascular permeability responses to histamine and bradykinin In comparison with controls, diabetic rats presented decreased vascular permeability responses to intracutaneous histamine and bradykinin as assessed by the amount of Evans blue previously given intravenously, which leaked to the injected skin area. Decreased permeability responses to histamine and bradykinin were also observed in normal animals pretreated with 2DG. Results are summarized in Figure 1.

Effect of indomethacin and chloroquine Intravenous administration to normal animals of indomethacin $\left(5 \mathrm{mg} \mathrm{kg}^{-1}\right)$ or chloroquine $\left(25 \mathrm{mg} \mathrm{kg}^{-1}\right), 30 \mathrm{~min}$ before testing, did not affect the subsequent response to intracutaneous histamine and bradykinin. Results are presented as intercepts and slopes of the log dose-response lines calculated by linear regression analysis for each treatment and corresponding matching controls (Table 5). 
Table 4 Mesenteric microvessels: influence of topical application of $1 \mathrm{mu}$ crystalline insulin on latency changes of the vasoconstrictor response to noradrenaline induced by histamine and bradykinin in normal animals and in animals pretreated with 2-deoxyglucose

Latency (s) of the response to noradrenaline

$(0.03 \mu \mathrm{g})^{a}$ following the application of

$\begin{array}{lccc}\text { Animals } & \text { Nil } & \text { Insulin + histamine } & \text { Insulin + bradykinin } \\ & & (0.03 \mu \mathrm{g}) & (0.03 \mu \mathrm{g}) \\ \text { Treated }^{c} & 17.4 \pm 0.9 & 20.1 \pm 2.5 & 18.5 \pm 1.8 \\ & (n=7) & (n=7) & (n=6) \\ \text { Untreated } & 16.3 \pm 1.4 & & >90 \\ & (n=6) & (n=6) & (n=6)\end{array}$

Time of contact of insulin with the preparation before the addition of any other drug was $3 \mathrm{~min}$.

${ }^{a}$ The response was characterized by the complete interruption of blood flow in one or more vessels (capillaries excluded) of the microscopic field. Histamine and bradykinin were applied $30 \mathrm{~s}$ and $15 \mathrm{~s}$ before noradrenaline, respectively. The doses of histamine and bradykinin were the minimum effective doses to prevent consistently the standard amount of noradrenaline from producing its vasoconstrictor action in untreated animals. Drugs were applied topically. Insulin alone produced no response of the preparation in both groups of animals. Results are mean \pm s.e.mean. Number of microscopic fields tested is indicated in parentheses.

${ }^{b}$ No vasoconstrictor effect was observed up to $90 \mathrm{~s}$ after the application of noradrenaline; drugs were then washed out.

${ }^{c}$ Animals were injected with 2-deoxyglucose $200 \mathrm{mg} \mathrm{kg}^{-1}$ by the intravenous route and used $3 \mathrm{~h}$ later.

\section{Discussion}

The data presented here provide further insight into functional alterations of microvessels in diabetes mellitus. Significance of observations on microvessels depends largely on precautions taken to maintain the tissues under a minimum of trauma (Zweifach, 1948). The methods employed were aimed at fulfil- ling such requirements, and though of low resolution, did not preclude the identification of marked differences between diabetic and control rats.

Microscopic observation of the responses of mesenteric microvessels in situ to topically applied drugs, revealed that the minimum effective doses of histamine and bradykinin, capable of antagonizing consistently in controls the vasoconstrictor effect of a

Table 5 Intercepts and slopes of the log dose-response lines calculated by linear regression analysis for bradykinin and histamine in indomethacin- or chloroquine-treated animals in comparison with matching controls

\begin{tabular}{|c|c|c|c|c|}
\hline \multirow[b]{3}{*}{ Treatment } & \multicolumn{4}{|c|}{ log dose-response lines ${ }^{a}$} \\
\hline & \multicolumn{2}{|c|}{ Bradykinin } & \multicolumn{2}{|c|}{ Histamine } \\
\hline & Intercept & Slope & Intercept & Slope \\
\hline None (controls) & $\begin{array}{c}12.50 \pm 0.96 \\
(41)\end{array}$ & $\begin{array}{c}27.30 \pm 2.30 \\
(40)\end{array}$ & $\begin{array}{c}-12.92 \pm 1.23 \\
(38)\end{array}$ & $\begin{array}{c}24.20 \pm 2.94 \\
(37)\end{array}$ \\
\hline Indomethacin $\left(5 \mathrm{mg} \mathrm{kg}^{-1}\right)$ & $\begin{array}{c}13.03 \pm 1.56 \\
(14)\end{array}$ & $\begin{array}{c}28.94 \pm 3.72 \\
(13)\end{array}$ & $\begin{array}{c}-10.00 \pm 2.52 \\
(11)\end{array}$ & $\begin{array}{c}21.52 \pm 6.00 \\
(10)\end{array}$ \\
\hline Chloroquine (25 $\mathrm{mg} \mathrm{kg}^{-1}$ ) & $\begin{array}{c}11.71 \pm 1.59 \\
(14)\end{array}$ & $\begin{array}{c}23.60 \pm 3.80 \\
(13)\end{array}$ & $-11.24 \pm 2.51$ & $\begin{array}{c}23.70 \pm 5.98 \\
\text { (13) }\end{array}$ \\
\hline
\end{tabular}



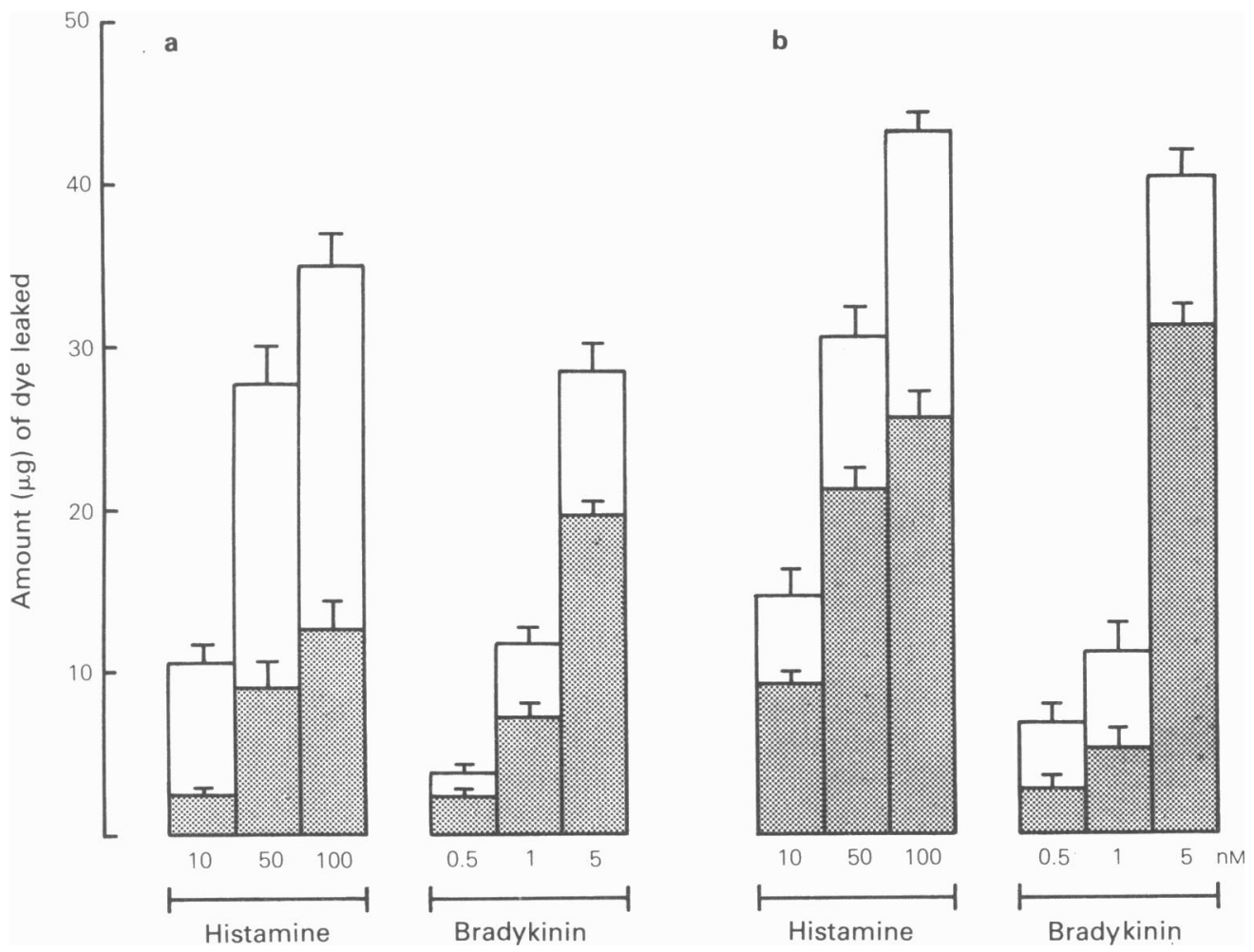

\begin{abstract}
Figure 1 Vascular permeability responses to intracutaneous histamine and bradykinin as assessed by the amount of exudation of Evans blue previously given intravenously. Intracutaneous injections were made in a standard volume of $0.1 \mathrm{ml}$. In (a) stippled areas denote the response of alloxan-diabetic animals; in (b), stippled areas denote the response of normal animals pretreated with 2-deoxyglucose $200 \mathrm{mg} \mathrm{kg}^{-1}$ by the intravenous route $3 \mathrm{~h}$ before. In both panels, unshaded areas denote the response of matching controls. Diabetes was induced by the injection of alloxan 10 days before. Results are mean values of 6 to 7 determinations. Vertical lines show s.e.mean. Differences between values in treated and untreated animals are statistically significant.
\end{abstract}

standard amount of NA, had to be increased about 20 fold to be effective in diabetic animals. ACh, however, remained equally active in both groups of animals as an antagonist to noradrenaline. This confirms previous findings (Fortes et al., 1983b).

Adrenalectomy performed in diabetic animals did not improve their capacity to respond to histamine and bradykinin. The finding apparently excluded the involvement of adrenal corticosteroids in the decreased sensitivity of the animals to the above agents. This is a relevant finding since many functional abnormalities in experimental diabetes are ameliorated by adrenalectomy (Long \& Lukens, 1936). On the other hand, the impaired responses of diabetic animals to histamine and bradykinin were reversed by a single topical application of crystalline insulin to the mesenteric preparation. The amount employed and the time of contact of the substance with the preparation were sufficiently limited to avoid changes in serum insulin or blood sugar levels. Insulin, therefore, seemed to exert its restorative effect through a direct action on microvessels. In addition, permeability responses demonstrated by local exudation of circulating dye at sites of intracutaneous injection of histamine and bradykinin, were noticeably reduced in diabetic animals as compared with controls. Accordingly, diabetes mellitus, already in its early stages, rendered rats hyporeactive to histamine and bradykinin acting as vasodilator or permeabilityincreasing factors.

Normal animals injected with 2-deoxyglucose (2DG) behaved as diabetic animals in that they were less responsive to histamine and bradykinin tested as vasodilator agents on mesenteric microvessels, or as 
permeability-increasing agents in the skin response. Administration of 2DG results in an acute cellular glucopaenia secondary to inhibition of glucose utilization (Kipnis \& Cori, 1959). Since 2DG prevents the penetration of glucose into cells (Wick et al., 1957), one should not expect insulin to be able to correct the resulting cellular defect. The finding described above and the observation that insulin did not improve the response of 2DG-treated rats to histamine or bradykinin, suggested that whenever a decreased plasma transfer of glucose to the reacting structures occurred, either in insulin-deficient states or secondary to inhibition of glucose utilization, reduced responses to histamine and bradykinin can be observed.

Based on experiments with large arteries in vitro, Furchgott \& Zawadzki (1980), Chand \& Altura (1981b,c) and De Mey \& Vanhoutte (1982) suggested that metabolic products of arachidonic acid might act as endogenous mediators for vascular relaxation. Pretreatment of normal animals with indomethacin produced no effect on their responses to histamine and bradykinin, tested as antagonists to NA on mesenteric microvessels, or as cutaneous vascular permeability-increasing agents. Therefore, it is unlikely that cyclo-oxygenase products of arachidonic acid might be responsible for the effects of histamine or bradykinin in the circumstances presently reported. In an attempt to interfere with the activity of phospholipase $A_{2}$, normal animals were injected with mepacrine, chloroquine or dexamethasone. Such substances are known to suppress phospholipase activity in vitro (Vargaftig \& Dao Hai, 1972; Flower \& Blackwell, 1976; Blackwell, et al., 1978; Authi \& Traynor, 1979; Morris, et al., 1979; Russo-Marie et al., 1979; Wallach \& Brown, 1981). Despite our lack of evidence that mepacrine and chloroquine can be similarly effective in vivo, some effects of anti-inflammatory glucocorticoids in vivo are attributable to an anti-phospholipase action mediated by an intracellular protein (macrocortin) whose synthesis and release are stimulated by the steroids (Blackwell et al., 1983). None of the ireatments employed altered the reactivity of mesenteric microvessels to histamine and bradykinin. Furthermore, vascular permeability responses were not affected by chloroquine. Though indirect, the present findings, which are in the line of evidence of recent

\section{References}

ALKSNE, J.F. (1959). The passage of colloidal particle across the dermal capillary under the influence of histamine. Q. J. exp. Physiol., 44, 51-66.

ALTURA, B.M., HALEVY, S. \& TURLAPATY, P.D.M.V. (1979). Vascular smooth muscle in diabetes and its influence on the reactivity of blood vessels. Adv. Microcirc., 8, 118-150. observations in vitro (Gordon \& Martin, 1983), suggested that the effects of histamine or bradykinin on microvessels are unlikely to be mediated by metabolic products of arachidonic acid.

Vascular permeability-increasing factors act directly on endothelial cells leading to open intercellular junctions (Alksne, 1959; Majno \& Palade, 1961; Fox et al., 1980; Heltianu et al., 1982). The event, which is mostly confined to post-capillary venules is rarely observed in diabetic animals challenged with permeability factors (Garcia Leme et al., 1974; Llorach et al., 1976). ACh is devoid of vascular permeability effects and, unlike histamine or bradykinin, its vasodilator potency was not rediced when tested in diabetic animals. Therefore, vasodilatation and increased vascular permeability evoked by histamine and bradykinin might be interrelated phenomena involving the participation of the endothelial cell. Increased osmolarity of extracellular fluid causes a significant delay in the vasoconstrictor response of microvessels to noradrenaline in normal and diabetic animals (Fortes et al., 1983b). Accordingly, histamine and bradykinin might antagonize the vasoconstrictor response of microvessels to noradrenaline through an action on venular endothelial cells with increased vascular permeability and temporary changes in composition of extracellular fluid. Marked extravasation of fluorescent tracer conjugated with serum albumin is observed in mesenteric vascular beds following application of histamine. A very high correlation is seen between the in vivo location of microvascular extravasation of the conjugated tracer and the location of gaps in the endothelium of venules or small veins, with accumulation of the material around the vessels (Fox et al., 1980). The effect of histamine and bradykinin on endothelial cells apparently depends on a direct facilitatory action of insulin to maintain an adequate plasma transfer of glucose to thc reacting endothelial cells. The results support the proposal that in insulindeficient states, early functional changes of the endothelial cell might contribute to the impaired reactivity of microvessels.

This work was supported in parts by grants from FINEP, Brazil. The expert secretarial assistance of Ms Yara Corradini is gratefully acknowledged.

AUTHI, K.S. \& TRAYNOR, J.R. (1979). Effects of antimalarial drugs on phospholipase $\mathrm{A}_{2}$. Br. J. Pharmac., 66, 496P.

BLACKWELL, G.J., CARNUCCIO, R., DI ROSA, M., FLOWER, R.J., IVANYI, J., LANGHAM, C.S.J., PARENTE, L., PERSICO, P. \& WOOD, J. (1983). Suppression of arachidonate oxidation by glucocorticoid-induced an- 
tiphospholipase peptides. In Advances in Prostaglandin, Thromboxane, and Leukotriene Research, vol.11. ed. Samuelsson, B., Paoletti, R. \& Ramwell, P. pp. 65-71. New York:Raven Press.

BLACKWELL, G.J., FLOWER, R.J., NIJKAMP, F.P. \& VANE, J.R. (1978). Phospholipase $A_{2}$ activity of guinea-pig isolated perfused lungs: stimulation, and inhibition by anti-inflammatory steroids. Br. J. Pharmac., 62, 79-89.

CHAND, N. \& ALTURA, B.M. (1981a). Acetylcholine and bradykinin relax intrapulmonary arteries by acting on endothelial cells: role in lung vascular diseases. Science, 213, 1376-1379.

CHAND, N. \& ALTURA, B.M. (1981b). Inhibition of endothelial cell-dependent relaxations to acetylcholine and bradykinin by lypoxygenase inhibitors in canine renal arteries. Microcirculation, 1, 211-223.

CHAND, N. \& ALTURA, B.M. (1981c). Endothelial cells and relaxation of vascular smooth muscle cells: possible relevance to lypoxygenases and their significance in vascular diseases. Microcirculation, 1, 297-317.

DE MEY, J.G. \& VANHOUTTE, P.M. (1982). Heterogenous behaviour of the canine arterial and venous wall. Importance of the endothelium. Circulation Res., 51, 439-447.

FLOWER, R.J. \& BLACKWELL, G.J. (1976). The importance of phospholipase- $\mathrm{A}_{2}$ in prostaglandin biosynthesis. Biochem. Pharmac., 25, 285-291.

FORTES, Z.B., GARCIA LEME, J. \& SCIVOLETTO, R. (1983a). Influence of diabetes on the reactivity of mesenteric microvessels to histamine, bradykinin and acetylcholine. Br. J. Pharmac., 78, 39-48.

FORTES, Z.B., GARCIA LEME, J. \& SCIVOLETTO, R. (1983b). Vascular reactivity in diabetes mellitus: role of the endothelial cell. Br. J. Pharmac., 79, 771-781.

FOX, J., GALEY, F. \& WAYLAND, H. (1980). Action of histamine on the mesenteric microvasculature. Microvasc. Res., 19, 108-126.

FURCHGOTT, R.F. \& ZAWADZKI, J.V. (1980). The obligatory role of endothelial cells in the relaxation of arterial smooth muscle by acetylcholine. Nature, 288, 373-376.

GARCIA LEME, J., BOHM, G.M., MIGLIORINI, R.H. \& SOUZA, M.Z.A. (1974). Possible participation of insulin in the control of vascular permeability. Eur. J. Pharmac., 29, 298-306.

GARCIA LEME, J., HAMAMURA, L., MIGLIORINI, R.H. \& LEITE, M.P. (1973). Influence of diabetes upon the inflammatory response of the rat. A pharmacological analysis. Eur. J. Pharmac., 23, 74-81.

GORDON, J.L. \& MARTIN, W. (1983). Stimulation of endothelial prostacyclin production plays no role in endothelium-dependent relaxation of the pig aorta. $\mathrm{Br}$. J. Pharmac., 80, 179-186.

HFLTIANU, C., SIMIONESCU, M. \& SIMIONESCU, N. (1982). Histamine receptors of the microvascular endothelium revealed in situ with a histamine-ferritin conjugate: Characteristic high-affinity binding sites in venules. J. cell Biol., 93, 357-364.

KING, E.J. \& GARNER, R.J. (1947). Colorimetric determination of glucose. J. clin. Pathol., 1, 30-33.

KIPNIS, D.M. \& CORI, C.F. (1959). Studies of tissue permeability. V. The penetration and phosphorylation of 2deoxyglucose in the rat diaphragm. J. biol. Chem., 234, $171-177$.
LLORACH, M.A.S., BÖHM, G.M. \& GARCIA LEME, J. (1976). Decreased vascular reactions to permeability factors in experimental diabetes. Br. J. exp. Path., 57, 747-754.

LONG, C.H.N. \& LUKENS, F.D.W. (1936). Effects of adrenalectomy and hypophysectomy on experimental diabetes in the cat. J. exp. Med., 63, 465-490.

MAJNO, G. \& PALADE, G.E. (1961). Studies on inflammation. I. The effect of histamine and serotonin on vascular permeability: An electron microscopic study. J. biophys. biochem. Cytol., 11, 571-605.

MORGAN, C.R. \& LAZAROW, A. (1963). Immunoassay of insulin: two antibody system: plasma insulin levels of normal, subdiabetic and diabetic rats. Diabetes, 12 , $115-126$.

MORRIS, H.R., PIPER, P.J., TAYLOR, G.W. \& TIPPINS, J.R. (1979). The effect of arachidonate lypoxygenase substrates and inhibitors on SRS-A release in the guineapig lung. Br. J. Pharmac., 66, 452P.

OSTERBY, R., GUNDERSEN, H.J. \& CHRISTENSEN, N.J. (1978). The acute effect of insulin on capillary endothelial cells. Diabetes, 27, 745-749.

RUSSO-MARIE, F., PAING, M. \& DUVAL, D. (1979). Involvement of glucocorticoid receptors in steroidinduced inhibition of prostaglandin secretion. J. biol. Chem., 254, 9498-9504.

SNEDECOR, G.W. \& COCHRAN, W.G. (1974). Statistical Methods, 6th ed. Ames, Iowa: State University Press.

VAN DEVOORDE, J. \& LEUSEN, I. (1982). Vascular endothelium and the relaxation effect of histamine on aorta of the rat. Archs. int. Pharmacodyn., 256, 329-330.

VARGAFTIG, B.B. \& DAO HAI, N. (1972). Selective inhibition by mepacrine of the release of "rabbit aorta contracting substance" evoked by the administration of bradykinin. J. Pharm. Pharmac., 24, 159-161.

WALLACH, D.P. \& BROWN, V.J.R. (1981). Studies on the arachidonic acid cascade. I. Inhibition of phospholipase $A_{2}$ in vitro and in vivo by several novel series of inhibitor compounds. Biochem. Pharmac., 30, 1315-1324.

WAYNFORTH, H.B. (1980). Experimental and Surgical Technique in the Rat., London:Academic Press.

WICK, A.N., DURY, D.R., NAKADA, H.I. \& WOLFE, J.K. (1957). Localization of the primary metabolic block produced by 2-deoxyglucose. J. biol. Chem., 224, 963-969.

WILHELM, D.L., MILL, P.J., SPARROW, E.M., MACKAY, M.E. \& MILES, A.A. (1958). Enzyme-like globulins from serum reproducing the vascular phenomena of inflammation. IV. Activable permeability factor and its inhibitor in the serum of the rat and the rabbit. Br. J. exp. Path., 39, 228-250.

WILLIAMS, Jr., J.R., HARRISON, T.R. \& GROLLMAN, A. (1939). A simple method for determining the systolic blood pressure of unanesthetized rat. J. clin. Invest., 18, $373-376$.

ZWEIFACH, B.W. (1948). Indirect methods for regional blood flow. I. Microscopic observation of circulation in rat mesoappendix and dog omentum. Use in study of vasotropic substances. Meth. med. Res., 1, 131-138.

(Received February 21, 1984. Revised July 9, 1984.) 